УДК 378.147.018.43:811.111

Кудлай $О$. I.

doi: 10.32620/gch.2019.2.09

\title{
УПРОВАДЖЕННЯ СИСТЕМИ МООDLЕ В НАВЧАЛЬНИЙ ПРОЦЕС ЯК ЕФЕКТИВНИЙ ЗАСІБ ВИВЧЕННЯ ІНОЗЕМНИХ МОВ
}

\begin{abstract}
Стаття присвячена проблемі впровадження системи Mоодle y процес навчання студентів іноземній мові. Автор презентує розроблення елемента дистаниійного курсу навчання англійської мови на початковому рівні.
\end{abstract}

Ключові слова: дистанційне навчання, іноземні мови, система Moodle.

The article is devoted to the problem of the introduction of the Moodle system into the process of teaching students a foreign language. The author presents the development of an element of the distance learning course in English at the elementary level.

Keywords: distance learning, foreign languages, Moodle system.

Актуальність теми. Розвиток інформаційних технологій впливає на всі сфери життя, зокрема й на освіту. Дистанційне навчання стає все більш популярним, оскільки дозволяє молодим людям здобути вищу освіту, навіть перебуваючи далеко від університету. Ця форма вже набула широкої популярності й застосовується багатьма освітніми закладами різних країн. В Україні дистанційне навчання на стадії становлення й активного впровадження. Заклади вищої освіти (ЗВО) розробляють дієві методики та створюють власні курси. Здебільшого така робота проводиться на базі системи Moodle.

Зважаючи на це, проблеми, пов'язані з розробленням теоретичних і практичних питань у цьому напрямку видаються найбільш актуальними. Водночас система дистанційної освіти на базі платформи Moodle створена на засадах соціальноконструктивної педагогіки, яка сьогодні привертає увагу багатьох дослідників, викладачів ЗВО.

Мета статті полягає в дослідженні переваг використання системи Moodle для вивчення іноземних мов.

Досягнення цієї мети потребує розв'язання таких завдань: ознайомитися 3 дослідженнями вітчизняних і зарубіжних учених стосовно дистанційного навчання; визначити поняття «дистанційне навчання»; визначити поняття «Moodle»; представити розробку дистанційного курсу іноземної мови для початкового рівня.

Стрімкий розвиток мережевих інформаційних технологій i всеохоплива інформатизація значно спрощують інформаційну, організаційну, навчальну та іншу діяльність, відкривають широкий спектр нових можливостей у сфері освіти.

На тлі інтенсивного темпу життя в сучасному світі необхідне впровадження сучасних мережевих інформаційних технологій у систему освіти, що надає змогу охочим здобувати знання й кваліфікацію 3 мінімальними витратами в часі, а також дає змогу 3 рівними можливостями навчатися мешканцям регіонів будь-якої 


\section{Кудлай О. I. УПРОВАДЖЕННЯ СИСТЕМИ МООDLЕ В НАВЧАЛЬНИЙ ПРОЦЕС ЯК ЕФЕКТИВНИЙ ЗАСІБ ВИВЧЕННЯ ІНОЗЕМНИХ МОВ}

віддаленості від місця розташування освітнього закладу, у тому числі й з інших країн. Такі технології об’єднують у спільну назву - «дистанційне навчання».

Дистанційне навчання тлумачать як організацію навчального процесу, за якої відбувається цілеспрямована безпосередня або опосередкована взаємодія учня (слухача) та викладача, розділених у просторі або часі, що здійснюється за допомогою сучасних інформаційних технологій, насамперед із використанням засобів телекомунікацій і мережі Інтернет. Упровадження дистанційної форми навчання $\epsilon$ основою для системи безперервної освіти, у якій технічні засоби та інформаційні освітні технології дають змогу не тільки змінити методику освоєння постійно зросталого обсягу знань, але й вести детальний контроль оцінювання та самооцінювання процесу навчання, підвищити самоосвітню активність людини [5].

Залучення інформаційних технологій у навчальний процес активно розглядають педагоги І. Роберт, I. Булах, Ю. Биков, Л. Пєтухова. Проблемам і особливостям упровадження дистанційної форми навчання присвячено праці Є.Полат, А. Хуторського, Р. Шарана. Використанням елементів дистанційного навчання студентів займаються Т. Коваль, Є. Смирнова-Трибульска, М. Прадівляний, Г. Яценко. Методичними принципами навчання іноземної мови та перекладацьких дисциплін із використанням інформаційно-комунікаційних технологій (IКT), засобів дистанційного навчання займаються О. Мацюк, А. Янковець, Л. Морська та ін.

На сьогодні для ЗВО нагальними є завдання створення відкритого й динамічного інформаційно-освітнього середовища як структурно впорядкованої системи навчання, інтегрованого засобу накопичення й реалізації інноваційного потенціалу навчального закладу, який об'єднує інтелектуальні, освітні, інформаційні, організаційні й технічні ресурси та сприяє інноваційному професійному зростанню суб'єктів навчання. Важливим компонентом такого середовища є програмні засоби управління навчанням (LMS, Learning ManagementS ystem), які в науковій літературі мають різну назву програмно-інструментальні платформи, системи дистанційного навчання, віртуальні навчальні середовища та ін. Але суть одна, вони створені для організації, управління й супроводу дистанційного навчання.

У період світової фінансової кризи важливим чинником вибору електронної навчальної платформи є іiі ціна. Тому більшість ЗВО України зупинили свій вибір на безкоштовних навчальних платформах (Acollab, ATutor, COSE, DodeboLMS, Dokeos, ELEDGE, Ganesha, ILIAS, LAMS, LON-CAPA, LRN, Moodle, OLAT, Open ACS, Open Cartable, Sakai, The Manhattan Virtual Classroom та ін.). Аналіз, здійснений К. Р. Колос, засвідчує, що система дистанційного навчання Moodle становить зручну платформу для розв'язування навчальних завдань у закладах післядипломної освіти й тим самим реалізації принципу «освіти впродовж життя» [2].

Moodle - це модульне об'єктно-орієнтоване динамічне навчальне середовище (Modular Object-Oriented Dynamic Learning Environment), розповсюджується безкоштовно як Open Soure проект (ліцензія GNUGPL), який дозволяє копіювати, використовувати та змінювати програмний код. Система Moodle призначена для організації навчання й управління ним у мережному середовищі з використанням IКТ. Вона надійна в експлуатації, є простою у використанні й адмініструванні, забезпечує 
безпеку інформації та іï передання від викладача до студента, здійснює оцінювання навчальних досягнень студентів, сумісна із стандартним програмним забезпеченням. У своєму базовому складі містить більше двадцяти типів ресурсів і програмних засобів. Спроектована відповідно до реалізації методів колективної діяльності суб'єктів навчання та орієнтована, насамперед, на організацію взаємодії між викладачем і учнями, хоча підходить і для організації традиційних дистанційних курсів, а також підтримки очного навчання [13].

Простий i ефективний інтерфейс не вимагає спеціальних навичок щодо створення електронних навчально-методичних матеріалів. Значна увага приділена безпеці інформації в навчальному середовищі, установленні паролів, обробці форм даних, зберіганню інформації, формуванню і підтримці в актуальному стані облікових записів користувачів, створенню контингентів академічних груп, що дає змогу викладачам записувати студентів на свої курси цілими групами [6].

Moodle перекладена десятками мов, зокрема й українською. Система використовувалась у 197 країнах світу в 2014 р. та у 229 країнах у 2019 р. Основними засобами, які дозволяють суб' єктам навчання спілкуватися між собою, є такі: форум засіб off-line спілкування, спільний для всіх студентів, розміщений на головній сторінці платформи; електронна пошта; обмін вкладеними файлами з викладачем; чат (chat) - засіб on-line спілкування між викладачами і студентами; обмін особистими повідомленнями.

До базового ядра системи Moodle можуть бути встановлені додаткові засоби, які можуть бути корисними для викладачів, наприклад: мобільний Moodle - для запису відео- й аудіофайлів у Moodle; Richmedia - для створення й перегляду мультимедійних презентацій у форматах flash та HTML5, OOHOOPop-upDictionary засіб, який подвійним кліком по слову відкриває його статтю у веб-словнику або Вікіпедії та ін. Головним розробником системи є Мартін Доугіамас з Австралії. Цей проект є відкритим, і в ньому бере участь і велика кількість інших розробників. Moodle написана на PHP з використанням SQL-бази даних (My SQL, Postgre SQL чи Microsoft SQL Server). Moodle може працювати з об'єктами SCO та відповідає стандарту SCORM [13].

На сьогоднішній день система Moodle дуже популярна у всьому світі. Ïї використовують у різних галузях, зокрема в освіті для вивчення різних дисциплін. Мовні дисципліни не є винятком. Хоча система напряму не призначена для ї вивчення, але має всі необхідні інструменти для створення ЕОР навчання, зокрема іноземних мов. Викладачі можуть створювати у системі Moodle мультимедійні ЕОР для організації освітнього процесу 3 мовних дисциплін. Це, в першу чергу, пояснюється тим, що мультимедіа - це взаємодія візуальних і аудіо ефектів під керуванням інтерактивного програмного забезпечення 3 використанням сучасних технічних і програмних засобів. Мультимедіаоб'єднує текст, звук, графіку, фото, відео в одному цифровому поданні. Інтеграція звуку, руху, образу і тексту створює нове, незвичайно багате за своїми можливостями освітнє середовище, з розвитком якого збільшиться й ступінь залучення студентів до процесу навчання [1].

Багато процесів і об’єктів можуть бути подані в динаміці їхнього розвитку, а 


\section{Кудлай О. I. УПРОВАДЖЕННЯ СИСТЕМИ МООDLЕ В НАВЧАЛЬНИЙ ПРОЦЕС ЯК ЕФЕКТИВНИЙ ЗАСІБ ВИВЧЕННЯ ІНОЗЕМНИХ МОВ}

також у вигляді 2-х або 3-х вимірних моделей, що викликає в користувача ілюзію реальності зображуваних об'єктів.

Б. Баскервілл і Т. Робб наводять результати успішного впровадження Moodle в університеті Кіото Сангіо й створення бізнес-курсу англійської мови 3 акцентом на вивчення письмової комунікації [7].

Станлей фокусує свою увагу на використанні лексичного словника для студентів у процесі читання свого курсу в Канадському університеті міжнародних досліджень за допомогою системи Moodle. Він розробив глосарій, який надає студентам відомості, необхідні лексичні одиниці, а також різноманітні можливості, щоб побачити речі в різних контекстах. Станлей приходить до висновку, що Moodle i iï модуль «Глосарій», зокрема, стали величезною допомогою для викладачів, пропонуючи студентам поповнити свій словниковий запас навіть за межами класної кімнати, та обмеженням класних годин навчання[14].

Гінкелман та Гросе в 2004 р. опублікували звітні результати експериментального тестування в процесі навчання аудіювання й читання в університеті Саппоро Гакуен. Вони дослідили: підходи до тестування, проектування тестів, підбір апаратного й програмного забезпечення, адміністрування, процедури розміщення й оцінювання результатів за допомогою цільового аналізу. Дійшли висновку, що система Moodle має достатньо апаратних ресурсів i $\epsilon$ доцільною технічною платформою для розміщення тестових випробувань для великої кількості студентів у короткі терміни 3 економією часу на оформлення й аналіз результатів випробувань [9].

Батесон пропонує створювати двомовні освітні ресурси, активно використовувати в системі Moodle такі типи програмних засобів, як HotPot, Glossary, Choice, Database, зв'язування ресурсів у єдиний зв'язний набір завдань, Windows Notepad у якості дошки, HTML ресурси замість офісних документів, HTML таблиці, тести для мотивації студентів, групи для збереження дублікатів курсів. Усі ці ідеї можуть бути корисними не тільки для викладачів іноземних мов, але й для студентів[8].

Молоней і Гутіеррез зазначають про результати використання системи Moodle в програмі CALL (Computer-assisted languagel earning) ESP (English for specific purposes) у коледжі інформатики й інженерно-технічних робіт, університет Ріцумеікан. Вони рекомендують викладачам використовувати систему Moodle в освітньому процесі й дійшли висновку, що вона $є$ позитивним і корисним освітнім інструментом, котрий доступний усім для використання, хоча не всі викладачі знають, як правильно застосувати Moodle в CALL і як це могло б допомогти студентам учитися онлайн. Проте ця система може бути ідеальним рішенням для реалізації змішаного й дистанційного навчання, оскільки вона забезпечує загальне електронне навчання або комунікаційну платформу в багатоканальному середовищі; дозволяє навчатися тільки тим студентам, котрі записані до певного курсу; мотивувати студентів різними стилями навчання; забезпечити завантаження електронних документів для студентів [12].

Гінкелман і Жонсон описують трирічну роботу щодо вирішення проблеми спільного онлайн використання контенту викладачами, які використовують систему 
Moodle, a саме - робота в колаборативних групах, створення власних матеріалів, використання змішаних аудіо-, відео- й текстової діяльності. Вони роблять висновок, що інтерактивна стратегія розвитку, яка грунтується на прямих потребах викладацької групи, має вирішальне значення для розроблення корисного інструментарію в системі Moodle, такого, як формати курсів і сховищ [10].

Джастин Хант визначає, що для ефективнішого проектування курсів з іноземних мов на основі системи Moodle потрібно використовувати відео- й аудіоконтент та інші ілюстративні матеріали для того, щоб покращити навчання учнів. Він $\epsilon$ вчителем англійської мови середньої школи в Японії й розробником безкоштовного набору додатків Poodll для системи Moodle. За допомогою цих додатків учителі й інструктори $з$ іноземних мов по всьому світу можуть легко спроектувати в системі Moodle навчальні курси з мовних дисциплін, які наповнені різним мультимедійним контентом. Також він створив безкоштовний навчально-інформаційний курс 3 використання цих додатків [11].

Е.Ю. Лемешко зауважує, що на кафедрі методики викладання іноземних мов, спільно з Інститутом додаткової безперервної освіти Національного дослідницького Томського політехнічного університету, у межах роботи за Федеральною цільовою програмою «Викладач вищої школи» були розроблені й проходять апробацію два навчальних курси в середовищі системи управління навчанням Moodle 3 дисциплін «Англійська мова» й «Німецька мова». Створені курси розраховані на дві категорії слухачів: аспірантів і викладачів. Слухачі отримують доступ на цю платформу, ознайомлюються з автором курсу й вимогами для успішного проходження навчання. На думку Е.Ю. Лемешко, у використанні Moodle для навчання іноземних мов є низка переваг для студентів: доступність навчання в будь-який час; слухач отримує доступ до комплекту необхідних навчальних матеріалів у сучасному електронному вигляді безпосередньо з програм навчального середовища; система оцінки знань (електронні тести) об’єктивна й незалежна від викладача; збільшується творчий та інтелектуальний потенціал за рахунок самоорганізації, уміння взаємодіяти 3 колегами-одногрупниками, розміщуючи власні файли, беручи участь у дискусії, вирішуючи проблеми, спілкуючись у форумі та чаті [3].

Крім переваг для студентів, існують і незаперечні переваги для викладачів, серед яких вільний графік, оскільки аудиторні заняття зведені до мінімуму або повністю відсутні; можливість автоматизувати систему оцінки знань; використання сучасних мультимедійних технологій у навчальних матеріалах; синхронне й асинхронне спілкування студентів між собою та з викладачем. Синхронне спілкування в системі Moodle було реалізоване за допомогою спроектованих відеоконференцій (вебінарів), а асинхронне передбачає використання електронного листування.

Розроблення дистанційного курсу іноземної мови для початкового рівня відбулося, оскільки в поточному навчальному році кафедрою іноземних мов Національного аерокосмічного університету ім. М. Є. Жуковського «XAI» ім. М. Є. Жуковського «XАI» було розроблено один дистанційний курс іноземної мови для початкового рівня. Кожен викладач кафедри вивчив принципи роботи в системі Moodle та створив власний елемент дистанційного курсу для навчання іноземній мові 


\section{Кудлай О. I. УПРОВАДЖЕННЯ СИСТЕМИ МООDLЕ В НАВЧАЛЬНИЙ ПРОЦЕС ЯК ЕФЕКТИВНИЙ ЗАСІБ ВИВЧЕННЯ ІНОЗЕМНИХ МОВ}

початкового рівня студентів як денної, так і заочної форми навчання. Подальша робота спрямована на розроблення дистанційних курсів для вищих рівнів навчання іноземним мовам [4].

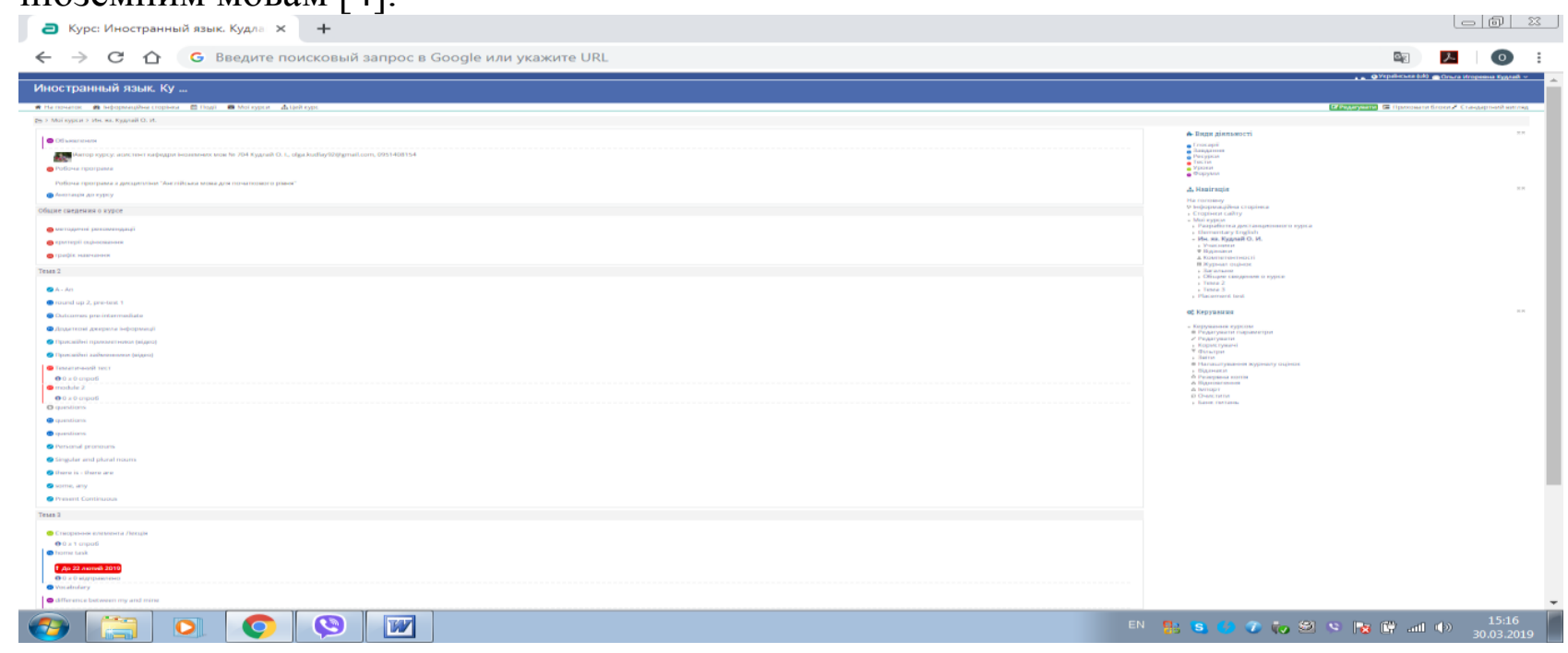

\section{Література:}

1. Коваль Т. І., Щербина О. А. Реалізачія технологій дистанційного навчання іноземних мов з використанням навчального середовища Moоdle // Неперервна професійна освіта: теорія і практика : науково-методичний журнал. 2011. Випуск 2. С. 97-104.

2. Колос К. Р. Система Moоdle як засіб розвитку предметних компетентностей учителів інформатики в умовах дистаниійної післядипломної освіти : дис. канд. пед. наук : 13.00.10. Житомир, 2011. 238 c.

3. Лемешко Е. Ю. Информачионные технологии в обучении английскому языку слушателей курсов повышения квалификации. 2010. URL: http://www.sworld.com.ual konfer26/510.pdf (дата звернення: 30.03.2019).

4. Сайт дистаниійного навчання Національного аерокосмічного університету «XAI». URL: https://mentor.khai.edu/course/view.php?id=276 (дата звернення: 30.03.2019).

5. Сташевський 3., Буряк Н. Інформачійно-комунікаиійні технології в сучасній освіті: досвід, проблеми, перспективи: зб. наук. пр. Третьої Міжнародної наук.-практ. конф. ; Львівський державний університет безпеки життєдіяльності. Львів, 2013.

6. Щербина О. А. Швидке створення облікових записів студентів та ӥх реєстрація в курсах платформи Mоodle 2 // Інформаційні технології в освіті: зб. наук. праџь, № 23. Херсон : Вид. Херсонськ. держ. ун-ту, 2015. C. 79-89, DOI: 10.14308/ite000538.

7. Baskerville B. \& Robb, T. Using Moodle for teaching business English in a CALL environment. PacCALL journal 1(1), 2005. Pp. 138-151.

8. Bateson G. Intermediate Moodle: Ideas for language teachers. The JALT CALL journal, 4(2), 2008. Pp. 73-79.

9. Hinkelman D., Grose T. Placement testing and audio quiz making with open source. To Moodle or not to Moodle (Nozawa) software. PacCALL journal, 1(1), 2005. Pp. 974-981.

10. Hinkelman D., Johnson A. Project format repositories for teacher collaboration. JALT CALL 2009 Proceedings, 2010. Pp. 41-45.

11. Justin Hunt developed Pood LL. URL: https:// moodle4teachers.org/course/view.php?id=81 (дата звернення: 30.03.2019).

12. Moloney B., Gutierrez T. An enquiry into Moodle usage and knowledge in a Japanese ESP program // PacCALL journal, 2(1), 2006. Pp. 48-60. 
13. Moodle. URL : https://uk.wikipedia.org/wiki/Moodle (дата звернення: 30.03.2019).

14. Stanley I. Creating a student-generated glossary in Moodle: How is it done and how effective is it? // The JALT CALL journal 3, 2007. Pp. 116-131.

\section{References:}

1. Koval, T. I. and Iuerbyna, O. A. (2011), "Realizatsiia tekhnolohii dystantsiinoho navchannia inozemnykh mov z vykorystanniam navchalnoho seredovyshcha Moodle" [Realization of technologies of foreign languages distance learning using the learning environment Moodle. Continuous vocational education: theory and practice], Neperervna profesiina osvita: teoriia i praktyka, No2, pp. 97-104.

2. Kolos, K. R. (2011), Systema Moodle yak zasib rozvytku predmetnykh kompetentnostei uchyteliv informatyky $v$ umovakh dystantsiinoi pisliadyplomnoi osvity [Moodle system as a means of developing the subject competences of computer science teachers in the conditions of distance postgraduate education]. MA dissertation. Zhytomyr.

3. Lemeshko, E. Y. (2010), "Informacionny'e texnologii v obuchenii anglijskomu yazy`ku slushatelej kursov povy'sheniya kvalifikacii" ["Information technology in training of English language students of advanced training courses"], available at: http://www.sworld.com.ua>

4. Nosikov, O.S. (2011), Sait dystantsiinoho navchannia Natsionalnoho aerokosmichnoho universytetu "KhAI» [Website of distance learning of National Aerospace University "KhAI"], available at: https://mentor.khai.edu/course/view.php?id=276> [30.03.2019].

5. Stashevskyi, Z. and Buriak, N. (2013), "Informatsiino-komunikatsiini tekhnolohii v suchasnii osviti: dosvid, problemy, perspektyvy”, Tretia Mizhnarodna naukovo-praktychna konferentsiia [Information and communication technologies in modern education: experience, problems, perspectives. Third International Scientific and Practical Conference], Lviv.

6. Iuerbyna, O. A. (2015), "Shvydke stvorennia oblikovykh zapysiv studentiv ta yikh reiestratsiia v kursakh platformy Moodle 2". Informatsiini tekhnolohii v osviti [The quick creating of student accounts and their registration in the courses of the Moodle 2. Information technologies in education], No 23, pp. 79-89.

7. Baskerville, B. and Robb, T. (2005), "Using Moodle for teaching business English in a CALL environment", PacCALL journal, No1, pp. 138-151.

8. Bateson, G. (2008) "Intermediate Moodle: Ideas for language teachers", The JALT CALL journal No4, pp. 73-79.

9. Hinkelman, D. and Grose, T. (2005), "Placement testing and audio quiz making with open source. To Moodle or not to Moodle (Nozawa) software”, PacCALL journal No1, pp. 974-981.

10. Hinkelman, D. and Johnson, A. (2010), "Project format repositories for teacher collaboration”, JALT CALL 2009 Proceedings, pp. 41-45.

11. Deutsch, N. (2009), Justin Hunt developed PoodLL[online], available at: https://moodle4teachers.org/enrol/index.php?id=81, [30.03.2019].

12. Moloney, B. and Gutierrez, T. (2006), "An enquiry into Moodle usage and knowledge in a Japanese ESP program”, PacCALL journal No 2 (1), pp. 48-60.

13. Wales, J. and Sanger, L. https://uk.wikipedia.org/wiki/Moodle> [30.03.2019].

14. Stanley, I. (2007), "Creating a student-generated glossary in Moodle: How is it done and how effective is it?", The JALT CALL journal 3, pp. 116-131.

\section{Olga Kudlay}

\section{THE INTRODUCTION OF THE MOODLE SYSTEM INTO THE EDUCATIONAL PROCESS AS AN EFFECTIVE METHOD OF STUDYING FOREIGN LANGUAGES}

The development of information technology affects all spheres of life, including education. Distance learning is becoming increasingly popular as it allows young people to 


\section{Кудлай О. I. УПРОВАДЖЕННЯ СИСТЕМИ МООDLЕ В НАВЧАЛЬНИЙ ПРОЦЕС ЯК ЕФЕКТИВНИЙ ЗАСІБ ВИВЧЕННЯ ІНОЗЕМНИХ МОВ}

receive higher education even being away from the university. This form has already gained wide popularity and is used by many educational institutions from different countries. In Ukraine, distance learning is at the stage of formation and active implementation. Higher Educational Institutions (HEIs) develop effective methods and create their own courses. For the most part, such work is carried out on the basis of the Moodle system.

In the view of this, the problems associated with the development of theoretical and practical issues in this direction appear to be the most relevant. At the same time, the system of distance education based on the Moodle platform is created on the basis of social constructive pedagogy, which today attracts the attention of many researchers, teachers of HEIs.

The purpose of the article is to explore the benefits of using the Moodle system for learning foreign languages.

The execution of this goal requires solving the following tasks:

- get acquainted with researches of domestic and foreign scientists regarding distance learning;

- define the concept of "distance learning";

- define the concept of "Moodle";

- introduce the development of a distance course of a foreign language for the elementary level.

Distance learning is interpreted as an organization of an educational process, in which there is a purposeful direct or indirect interaction between a student (a listener) and a teacher, separated in space or in time, carried out on the basis of modern information technologies, primarily through the use of telecommunications and the Internet. The implementation of distance learning forms the basis for a system of continuous education, in which technical means and informational educational technologies enable not only to change the methodology of developing an ever-increasing amount of knowledge, but also to carry out a detailed control of the assessment and self-assessment of the learning process, to enhance the self-education of a person.

The involvement of information technology in the educational process is actively considered by the teachers I. Robert, I. Bulakh, Yu. Bykov, L. Petukhov. The works of E. Polat, A. Khutorsky, R. Sharan are devoted to the problems and peculiarities of the introduction of the distance learning form. T. Koval, E. Smirnova-Trybulsk, M. Izdyliany, G. Yatsenko consider using the elements of students' distance learning. Methodical principles of teaching a foreign language and translation disciplines using information and communication technologies (ICT), means of distance learning are examined by O. Matsyuk, A. Yankovets, L. Morskaya and others.

Moodle is a Modular Object-Oriented Dynamic Learning Environment, distributed free of charge as an Open Source project (GNU GPL license) that allows you to copy, use, and modify the code. The Moodle system is designed to organize and manage learning in a networked environment using ICT. It is reliable in operation, easy to use and administrate, provides information security and its transfer from a teacher to a student, makes assessment of students' achievements, is compatible with standard software.

This academic year one distance course of a foreign language for the elementary level 
has been developed by the department of foreign languages number 704 of the National Aerospace University «Kharkiv Aviation Institute». Each teacher of the department has studied the principles of work in the system of Moodle and created their own element of the distance course for teaching a foreign language for elementary level students of both fulltime and part-time study. Further work is aimed at developing distance courses for higher levels of foreign language learning.

Keywords: distance learning, foreign languages, Moodle system.

\section{Ольга Кудлай}

\section{УПРОВАДЖЕННЯ СИСТЕМИ МООDLЕ В НАВЧАЛЬНИЙ ПРОЦЕС ЯК ЕФЕКТИВНИЙ ЗАСІБ ВИВЧЕННЯ ІНОЗЕМНИХ МОВ}

Розвиток інформаційних технологій впливає на всі сфери життя, зокрема й на освіту. Дистанційне навчання стає все більш популярним, оскільки дозволяє молодим людям отримати вищу освіту, навіть перебуваючи далеко від університету. Ця форма вже набула широкої популярності й застосовується багатьма освітніми закладами різних країн. В Україні дистанційне навчання на стадії становлення і активного впровадження. Заклади вищої освіти (ЗВО) розробляють дієві методики та створюють власні курси. Здебільшого така робота проводиться на базі системи Moodle.

Зважаючи на це, проблеми, пов'язані з розробленням теоретичних і практичних питань у цьому напрямку видаються найбільш актуальними. Водночас система дистанційної освіти на базі платформи Moodle створена на засадах соціальноконструктивної педагогіки, яка сьогодні привертає увагу багатьох дослідників, викладачів ЗВО.

Мета статті полягає в дослідженні переваг використання системи Moodle для вивчення іноземних мов.

Виконання цієї мети потребує розв'язання таких завдань:

- ознайомитися 3 дослідженнями вітчизняних і зарубіжних вчених стосовно дистанційного навчання;

- визначити поняття «дистанційне навчання»;

- визначити поняття «Moodle»;

- представити розроблення дистанційного курсу іноземної мови для початкового рівня.

Дистанційне навчання тлумачиться як організація навчального процесу, за якої відбувається цілеспрямована безпосередня або опосередкована взаємодія учня (слухача) та викладача, розділених у просторі або в часі, що здійснюється на основі сучасних інформаційних технологій, насамперед 3 використанням засобів телекомунікацій та мережі Інтернет. Упровадження дистанційної форми навчання $є$ основою для системи безперервної освіти, у якій технічні засоби та інформаційні освітні технології дають змогу не тільки змінити методику освоєння постійно зростаючого обсягу знань, але й вести детальний контроль оцінювання та самооцінювання процесу навчання, підвищити самоосвітню активність людини. 


\section{Кудлай О. І. УПРОВАДЖЕННЯ СИСТЕМИ МООDLЕ В НАВЧАЛЬНИЙ ПРОЦЕС ЯК ЕФЕКТИВНИЙ ЗАСІБ ВИВЧЕННЯ ІНОЗЕМНИХ МОВ}

Залучення інформаційних технологій у навчальний процес активно розглядають педагоги I. Роберт, І. Булах, Ю. Биков, Л. Пєтухова. Проблемам і особливостям впровадження дистанційної форми навчання присвячено праці Є. Полат, А. Хуторського, Р. Шарана. Використанням елементів дистанційного навчання студентів займаються Т. Коваль, Є. Смирнова-Трибульска, М. Прадівляний, Г. Яценко. Над методичними принципами навчання іноземної мови та перекладацьких дисциплін із використанням інформаційно-комунікаційних технологій (IКТ), засобів дистанційного навчання працюють О. Мацюк, А. Янковець, Л. Морська та ін.

Moodle - це модульне об'єктно-орієнтоване динамічне навчальне середовище (Modular Object-Oriented Dynamic Learning Environment), розповсюджується безкоштовно як Open Source проект (ліцензія GNU GPL), який дозволяє копіювати, використовувати та змінювати програмний код. Система Moodle призначена для організації й управління навчанням у мережному середовищі з використанням IКТ. Вона надійна в експлуатації, $є$ простою у використанні й адмініструванні, забезпечує безпеку інформації та її передачу від викладача до студента, здійснює оцінювання навчальних досягнень студентів, сумісна із стандартним програмним забезпеченням.

У поточному навчальному році кафедрою іноземних мов Національного аерокосмічного університету ім. М. Є. Жуковського «XАI» було розроблено один дистанційний курс іноземної мови для початкового рівня. Кожен викладач кафедри вивчив принципи роботи в системі Moodle та створив власний елемент дистанційного курсу для навчання іноземній мові початкового рівня студентів як денної, так i заочної форми навчання. Подальша робота спрямована на розроблення дистанційних курсів для вищих рівнів навчання іноземним мовам.

Ключові слова: дистаниійне навчання, іноземні мови, система Moоdle.

Kudlay Olga - Assistant of the Department of Foreign Language Faculty of Humanities of the National Aerospace University «Kharkiv Aviation Institute».

Кудлай Ольга - асистент кафедри іноземних мов гуманітарного факультету Національного аерокосмічного університету ім. М. Є. Жуковського «Харківський авіаційний інститут».

e-mail: olga.kudlay92@gmail.com

Надійшла до редакції 06.05.2019. Розглянута на редколегії 14.06.2019.

\section{Рецензенти:}

Кандидат філологічних наук, доцент кафедри іноземних мов гуманітарного факультету Національного аерокосмічного університету ім. М. Є. Жуковського «ХАІ» Чубукіна О. В.

Кандидат педагогічних наук, доцент кафедри іноземних мов гуманітарного факультету Національного аерокосмічного університету ім. М. Є. Жуковського «ХАІ» Шульга I. М. 